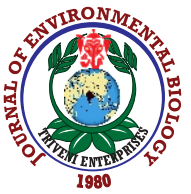

\title{
A review on the improvement of cladocera (Moina) nutrition as live food for aquaculture: Using valuable plankton fisheries resources
}

\author{
N.W. Rasdi ${ }^{1,5 *}$, A. Arshad ${ }^{2}$, Mhd. Ikhwanuddin ${ }^{3}$, A. Hagiwara ${ }^{4}$, F. Md. Yusoff ${ }^{2}$ and N. Azani ${ }^{1}$ \\ ${ }^{1}$ Faculty of Fisheries and Food Science, Universiti Malaysia Terengganu, Kuala Nerus 21300, Malaysia \\ ${ }^{2}$ International Institute of Aquaculture and Aquatic Sciences, Universiti Putra Malaysia, 71050 Port Dickson, Negeri Sembilan, Malaysia \\ ${ }^{3}$ Institute of Tropical Aquaculture and Fisheries, Universiti Malaysia Terengganu, Kuala Nerus 21300 Malaysia \\ ${ }^{4}$ Graduate School of Fisheries and Environmental Sciences, Bunkyo 1-14, Nagasaki 852-8521, Japan \\ ${ }^{5}$ Institute of Tropical Biodiversity and Sustainable Development, Universiti Malaysia Terengganu, 21300, Kuala Nerus, Terengganu, Malaysia \\ *Corresponding Author Email : nadiah.rasdi@umt.edu.my
}

\section{Abstract}

This review focuses on the potential of Moina sp. as a promising live feed in aquaculture, as well as on low-cost enrichment methods, which can improve nutrition levels available from this live feed species.

Since formulated feed for this purpose has not yet been established effectively, the features of live feeds in the performance of marine and freshwater larval rearing is essential. Hence, to succor growth productivity and to introduce newly livestock species into aquaculture industry, support for the stage of larval rearing must be improved and, better nutritional options must be applied. Furthermore, the natural feeding habits of fish needs live food rich in protein for improved growth, enhanced reproduction as well as survival. Common enrichment protocols, such as oil emulsion, are relatively expensive and consequently, increase overall production cost in hatcheries. The above factors have moved scientists to focus more on development of low-cost, live feed substitutions to ensure success of larval feeding in aquaculture. Larval feed performance depends directly on improvements in finding a better low-cost live feed technology for a better zooplankton and phytoplankton production.

Cladocerans like Moina sp. have recently been explored as a potential live feed alternative to boost fish and shrimp larval cultivation in hatcheries. The increase in demand for fish as a source of protein for human consumption requires advancement in the development of aquaculture technologies and, emphasis is well placed on improving supply of live food organisms to assist in the larval development process.

The continuous production of live food organisms is prerequisite to fish and shrimp larval growth and survival in hatcheries.

Key words: Aquaculture live feed, Low-cost, Moina, Nutrition, Zooplankton

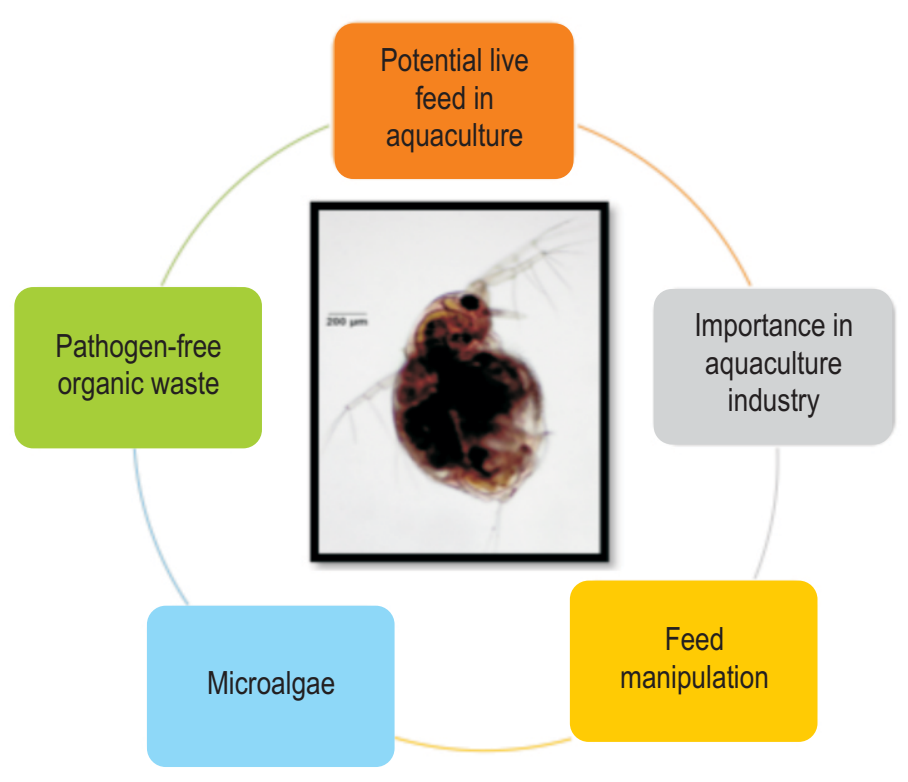

How to cite : Rasdi, N.W., A. Arshad, Mhd. Ikhwanuddin, A. Hagiwara, F. Md. Yusoff and N. Azani: A review on the improvement of cladocera (Moina) nutrition as live food for aquaculture: Using valuable plankton fisheries resources. J. Environ. Biol., 41, 1239-1248 (2020). 


\section{Introduction}

The continuous production of larvae in aquaculture systems depends on the planktons that have been enclosed with important nutrients (Budhin et al., 2016). Availability of suitable live feed for feeding finfish and shellfish larvae has led to successful propagation of hatchery-reared species (Pronob et al., 2012). Supplying adequate live food for fish larvae is important and the nutritional quality of living food species can be improved by enriching the nutrients (Rasdi and Qin, 2016a; Rasdi and Qin., 2018b). Live feed species in larvae and early post-larvae stages of various fish are more beneficial than artificial feed and shellfish species, since zooplankton are known to be an important food for animals in natural aquatic habitats where they pass on the organic matter to higher trophic levels from phytoplankton and detritus (Das et al., 2007; Parakrama et al., 2012; Abbas et a.l, 2015). Larvae consumption of zooplankton constitutes major part of their nutritional intake with zooplankton also playing a major role in recycling nutrients and sources of energy within their respective food web (Kar et al., 2017; Miah et al., 2013).

The diet of larval fish in aquaculture primarily depends on the use of brine shrimp (Artemia spp.), especially for starter feed in the larval rearing of most fish and crustaceans. Nevertheless, brine shrimp price is the major restraint for poor-resource farmers in the developed countries but required to continuously use this species in feeding hatchery-reared larvae (Ngupula et al., 2014). The live food species are the most important resource for aquaculture in an aquatic environment and most fish larvae and shellfish in nature directly feed on small zooplanktonic species (Pronob et al., 2012). Live food organisms are commonly referred to as "living nutritional capsules" because they contain natural essential nutrients and energy sources such as proteins, lipids, carbohydrates, vitamins, minerals, fatty acids and amino acids that are needed in aquaculture for the growth and maintenance of majority of cultivated species (Mona et al., 2017).

The major management aspect in farming of both finfish and shellfish is proper management of feeding. In order to minimize larval production cost and, maximize the overall production level in hatcheries, good larval feed is important for the rapid growth of young fish and prawns (Rimmer et al., 2011). Major factors such as availability, nutritional requirement of larval fish and shellfish, size of feed that fits the mouth gape of larval fish and, high nutritional value complement selecting zooplankton as live feed for larvae (Budhin et al., 2016). Since no artificial larval diet can fully satisfy larval nutritional requirements, good rearing still depends on a suitable supply of best quality plankton, usually in the common form of rotifers Brachionus plicatilis and brine shrimp Artemia salina. Consequently, the development of live feed is mostly restricted to Artemia nauplii, which is matured after incubating dry eggs (cysts) (Parisi et al., 2014). Moreover, live prey feeding typically takes $40-50$ days, depending on the temperature of water and the procedure for rearing before fish are transferred to an artificial diet (weaning). In recent years, the timing of first dry food source has been continually pushed to an earlier date by the use of new, more complex artificial foods that also include antioxidants and immunostimulants and better meet the larval requirements in terms of structure, size, buoyancy and taste (Villamizar et al., 2009). However, fish larvae had showed poor response towards artificial diet due to inadequate growth of their digestive system during early feeding cycle with low digestive enzyme production (Akbary et al., 2010). Furthermore, zooplankton provides good digestive enzymes of trypsin and pepsin that is vital to fish larvae during early stages of development (Ronnestead et al., 2013).

In most hatcheries, feeding regimes for early larval stages are often dependent on rotifers and Artemia followed by artificial pelleted diets. Rotifers are common larval live feeds used in both marine and freshwater hatcheries due to their small size that can be accommodated by the mouth gape of fish larvae (Velasco et al., 2011). However, mass culture of rotifers often carry risks of sudden mortality which may result from contamination of populations by ciliates or, pathogenic bacteria . Therefore, there is a need to develop other reliable continuous cultures of potential zooplankton species with high nutritional value to assist larval feeding in hatcheries). Even though many live food organisms commonly used in larviculture own a nutritional value higher than that of formulated diets, certain live food zooplanktons are selected as a food source in larviculture depending on qualities including purity, acceptability, nutrient indicators (digestibility and nutrients / organism energy), ease of availability, reliable and quick reproduction and, economically viable. Cladoceran culture offers the possibility of obtaining several living food organisms throughout short period of time when developed under optimum temperature, air, and water quality conditions. Furthermore, the cladocerans, Moina sp. and Daphnia sp. are both valuable sources of protein, inexpensive to produce and, can serve as an option to Artemia. Both species have high reproduction rates, wide environmental tolerance, and an ability to feed phytoplankton and organic waste medium (Samir et al., 2015).

Cladocerans display remarkable tolerance to abrupt increase in salinity as in several species of Daphnia exilis, Bosmina coregoni and Daphnia longispina (Heine-Fuster et al., 2010; Zorina-Sakharova et al., 2014 and Leitao et al., 2013). Most fish larvae show a preference for cladocerans because of their whimsical movement, that make them more obvious to their prey (Mayer et al., 1997; Budhin et al., 2016). Moina are suitable for fry of freshwater fish and, most freshwater fish species can digest little Moina as their first meal (Rottman et al., 2014). Moina is ideal for use in aquaculture because of easy handling, fast reproduction, non-selective filter feeding of bacteria in solution, high nutritional value, and suitable for a large variety of conditions (Oh et al., 2012; Samuel, 2014). Since the use of Artemia is costly, 
Moina can be a suitable candidate to replace them for feeding fry. It is also highly recommended to use live Moina in the hatchery as a replacement to Artemia since it can be easily grown in fresh water and can be easily digested by frying (Okunsebor et al., 2010).

This review article discusses enrichment of Moina by using different media for improving dietary composition of Moina to make them fit for larval feeding. This review focuses on the biology of feeding and the media culture of Moina, the basic principles of nutritional requirements, and application of Moina to fish and shrimp larval feeding in hatchery. Specifically, the current study discusses the application of Moina in aquaculture as live feed, evaluates nutritional composition of Moina, reviews current live food enrichment methods for Moina culture and demonstrates the current culture practices applied to Moina.

Moina: Among the richest species diversity: The genus Moina is known to dominate North and South American, Australia, China, tropical Asia as well as Eurasia waters, where the number of moinid species in these areas are comparable to that in Daphnia, which further indicates that Moina is one of the largest genera of Cladocera in these regions (Bekker et al., 2016; Wang et al., 2009; Alonso et al., 2019). Due to the virtue of high reproduction rates, moinids are utilized as one of the potential foods for fish larvae in commercial aquaculture (Dumont et al., 2013). Moina is a small freshwater microcrustacean and is one of the most commonly found freshwater zooplankton in Malaysia (Sinef and Yusoff, 2018). Cladocerans are one of the microcrustaceans, these are considered major secondary consumers in their natural surroundings, as the highest filtration rate among freshwater zooplankton in the ecosystem exists (Dumont et al., 2013; Lim et al.,1984). Moina also demonstrates a broad range of ability to adapt to various environmental parameters (Rizo et al., 2016). Moinids are narrow to average zooplankton species that are usual in tropical waters and along with daphniids, and are generally recognized in limnetic water bodies (Fernando, 2002; Rizo et al., 2017). One of the cladoceran species of Moina micrura has been recorded in diverse environments, from freshwater to brackish hyper-eutrophic estuary (Paranhos et al., 2013, Moreno etal., 2019).

Use of Moina as live feed in shrimp, fish, shellfish and ornamental fish aquaculture: Fish larvae and shellfish diet requires adequate amount of carbohydrates, lipids, vitamins and minerals (Watanabe et al., 1994; Kanazawa et al., 2003; Budhin et al., 2016). Deficiency of any required nutrient may lead to poor growth, anemia, high mortality and / or low feed efficiency in rearing fish larvae and shellfish (Karlsen et al., 2015; Olivotto et al., 2003; Budhin et al., 2016). In aquatic trophic systems, cladocerans occupy the primary consumer level of extensive zooplankton commonly found in freshwater bodies. In recent years, cladocerans such as Moina and Daphnia have received much attention in the aquaculture industry (Saini et al., 2013). As filter feeders, cladocerans ingest nanoplankton, phytoplankton, detritus, bacteria and particles of different sizes. Furthermore, cladocerans are then devoured as an important naturally available component of fish diets (Nandini et al., 2013; Qin et al., 1996; Suresh et al., 2000; Srivastava et al., 2006; Hudson et al., 1999; Li etal., 2017).

Cladocerans are preferred by most fish larvae and successfully used as food in the fish farming industry for fish larvae (Taghavi et al.,2013; Armin et al., 2014). Cladocerans are considered palatable and attractive food for many ornamental fish and prawn seed (Saini et al., 2013). This specie contain a high protein as well as digestive enzymes, such as peptidases, proteinases, lipases and amylases in their intestines, which can act as exoenzymes in the gut of fish larvae (Miah et al., 2013). Moina is effectively used throughout inland aquaculture as larval live feed (Qin et al, 1996; Budhin et al, 2016), and used as a replacement live feed for Artemia (Alam et al., 1993; Armin et al., 2014; Kotani et al., 2016). It was proposed that the use of Moina enhances condition of different fish both young and adult stages (FRSS 2005; Kushniryk etal., 2015).

Moina is suitable for use in the aquaculture applications because it is simple to handle, reproduces easily, is a nonselective filter feeder for solution bacteria, has high nutrient value and is adaptable to different environmental conditions (Ricardo, 1981; Samuel, 2014). Moina species may also be considered a promising species for feeding fish larvae and fingerlings as they have a short lifespan, abundant energy storage, small size, and short embryonic stage (Sipauba-Tavares et al., 2014; Samuel, 2014). Moina macroocopa is a cladoceran mostly found in water bodies and plays a role in food chains in the aquatic environment (lannacone and Alvarino, 2000; Vignatti et al., 2013) and, has economic importance arising from its use in aquaculture as live food for fish larval stages (Vignatti et al., 2013; Rasdi et al., 2019). Tawaratmanikul (1988) reported that Clarius batrachus, Ompok bimaculatus, Lates calcarifer and Channa striatus fish larvae show improved growth and survival for cladorans as live feed (Amornsakun et al., 2001; Budhin et al., 2016). Since the used of Artemia is costly, Moina can replace them as a suitable candidate for feeding fry. Thorough use of Moina in the hatchery is strongly recommended as a substitute of Artemia, since it is readily cultivated in fresh water (Okunsebor et al., 2010).

The nutritional value of Moina's depends on the stage of life cycle and the form of food obtained (Budhin et al., 2016). The average protein content of Moina is $50 \%$ dry and adults typically have higher fat content (20-27\%), then juveniles (4-6\%) (War et al., 2011; Rottman et al., 2014). When cultured in different media, fatty acid contents vary in Moina (Bouchnak et al., 2014; Loh et al., 2012; Gama-Flores et al., 2015). Like other live feeds, Moina does not fully satisfy the demands of heavily unsaturated fatty acids (HUFA) of larvae fish and crustaceans (Kamrunnahar et al., 2019). Hence, enrichment of Moina is important to improve the 
nutritional content of Moina for fish growth

Feeding Moina to fish fry as a mono diet can generally give comparatively better results than feeding a mixed diet or feeding other live feeds, although results are dependent on the specific requirements of fish cultured. Okunsebor et al. (2010) showed best performance of Heteroclarias fry (African catfish) when fed on Moina alone when compared with a mixed diet (Moina and Artemia). In fact, the best mean weight gain of goldfish fry (Carassius auratus) was recorded for fry fed with Moina in comparison to other diets tested (Okunsebor and Ofojekwu, 2003; Samuel, 2014). However, Moina can be used alone or, in combination with Artemia when fed to Macrobrachium rosenbergii without any adverse effect on production (Alam et al., 1991; Rahman et al., 2003).

Although Artemia being the most frequently used for larval feeding, the seasonal variation and expensive cost often limit their use in aquaculture hatcheries, and hence it is a requisite to develop low cost live feed organisms which are easy to culture like Moina in order to minimize risk to aquaculture practice during early larval development stages (Singh et al., 2012). Moreover, the use of Moina as fish larval feed has yielded commendable results with indigenous species in various regions of the world (Bryant and Marty, 1980; Adeyemo et al., 1994; Samuel, 2014). Moina has been utilized as an ideal food organism for carp, shrimp and catfish larvae (Singh et al., 2019; Islam et al., 2017). In India and Thailand, Moina has also been used in shrimp hatcheries (Rahman et al., 2003).

Nutritional value comparison of live food organisms: Artemia is famous as solitary live feed for commercially cultured larvae fish for several decades, and their amino acid profile has been well approved (Watanabe et al., 1978, 1983; Solomon et al., 2006; Dararat et al., 2012). On the other hand, the amino acid profile of freshwater zooplankton has been poorly documented, although these species are increasingly relevant as larvae feeds in hatcheries for freshwater fish (Solomon et al., 2006). The nutritional value of Moina differs according to the culture media used and life- cycle. Adult Moina usually have higher protein composition than juveniles. However, Moina has a higher nutritional value when compared with Artemia and, furthermore both species breed and grow faster (Mubarak et al., 2017) making Moina comparable to that of Artemia (Mubarak et al., 2017). As compared to other live foods, the cladocerans are high in protein as well as other nutrients (Alam et al., 1993; Altaff et al., 2010; Loh etal., 2012).

The moisture content of Moina species, approximately $87.9-89.0 \%$, is similar to other live foods such as Daphnia (88.1 $89.3 \%)$, Branchionus plicatilis (86.4 - 91.8\%) and Tigriopus japonica (86.0 - 87.3\%) (Watanabe, 1978, 1983; Solomon et al., 2006). With respect to crude protein content, Moina (59.95 $62.6 \%$ ) had the highest protein content when compared with
Daphnia (62.6\%) and B. plicatilis (52.15 - 60.57\%) (Watanabe, 1983; Solomon et al., 2006). Bogut et al. (2010) claimed that $D$. magna contained $39.24 \%$ and $33 \%$ which is relatively lower than Moina in fresh and dry weight, which is lower than the equivalent values determined for Moina. Solomon et al. (2006) stated that the moisture content of $M$. micrura was around $89 \%$, while crude protein was $52.4 \%$ of dry weight. $M$. micrura recorded higher amino acid concentrations than Diaphanosoma excisum and $B$. calyciflorus, except for alanine, tyrosine, threonine, proline and serine amino acids (Solomon et al., 2006). The main amino acid identified for M. micrura was lysine, and glutamine is the main non-essential amino acid (Solomon et al., 2006).

Amino acid levels in the profile of Moina were higher than for Artemia except for alanine, glycine, proline, serine, and tyrosine (Watanabe et al., 1983; Solomon et al., 2006). M. micrura was reported to contain sufficient crude protein and amino acid concentration to provide basic requirements of larvae and postlarvae feed that are essential to the survival and growth of fry and larval cultivated species (Solomon et al., 2006). Meanwhile, M. mongolica had most essential amino acids less than Artemia and $B$. plicatilis, but, methionine content in $M$. mongolica (1.5\%) was greater than Artemia (0.9\%) and B. plicatilis (0.8\%) (Tong et al., 1988; Budhin et al., 2016; Khudyi et al., 2018). Therefore, $M$. mongolica can serve as a supply medium in terms of methionine levels for fish larvae. For unsaturated fatty acids, M. mongolica recorded high eicosapentaenoic acid levels (EPA) (12.7\%) of total fatty acids, while in Artemia and B. plicatilis EPA level was recorded low, i.e., 2.1\% and 1.9\%, respectively (Tong et al., 1988; Budhin et al., 2016; Singh et al., 2019).

It can be summarized that the nutritional content of Moina was higher as other live foods and can be a reliable and affordable replacement for costly marine Artemia. In fact, Lavens and Sorgeloos (1996) believed that Artemia cysts are less nutritious than other zooplanktons (Solomon et al., 2006).

Enrichment of Moina species: Cladocerans tend to grow aggressively in water suspended organic microscopic particles (phytoplankton, bacteria, protozoans and fungi). (Rodolfo et al., 1980; Balayla et al., 2004; Kim et al., 2008; Budhin et al., 2016). Moina can feed on bacteria, algae and organic detritus (Samir et al., 2015). Moina culture density can also be enhanced by fecundity optimization and somatic development which can be achieved through regulation of quality and quantity of feed (Mubarak et al., 2017). Several feeds, including algae and artificial diets can be fed to Moina in order to enrich their nutritional value (Rasdi and Qin, 2018d). Enhancement of nutrition of cladoceran through enrichment of feed appears to be a good practice (Parakrama et al., 2012).

Similar to other live feeds, Moina does not really provide enough nutrients necessary for larval growth (Das et al., 2007; Parakrama et al., 2012). The dietary content of Moina is actually 
not favorable for small fish and shellfish, hence Moina must be supplemented with algae and / or artificial feed to improve its nutrition to that specific cultivation of a particular larval species. Live food enrichment strategies improve the importance and ability of live food to contribute as larval aquatic species in captive conditions are rising (Pronob et al., 2012; Rasdi and Qin, 2018a). As demonstrated for Artemia nauplii and rotifers, the nutritional value of Moina can be enhanced by enrichment through provision of various culture media (Watanabe et al., 1993; Das et al., 2007; Loh et al., 2016).

Microalgae : In aquaculture, microalgae fill an important role of enriching zooplankton before they are fed to fish or other larvae wherein microalgae nutrients are shifted through zooplankton intermediates to higher trophic levels (Brown et al., 1997; Guedes et al., 2015). Algae are the most important and common sources influencing feed value of herbivorous zooplankton such as cladocerans and rotifers (Hypolite et al., 2014). They provide key nutrients like vitamins, PUFA, pigment, and sterols in addition to providing protein (essential amino acid) as energy sources for zooplankton organisms. The levels of protein (12-35\%), lipids (7.2 - 23\%), and carbohydrates (4.6 - 23\%) recorded for algae species varies depending on differences between species and methods of production (Guedes et al., 2015). Microalgae species that are most widely used in aquaculture are Isochrysis sp., Chlorella sp., Tetraselmis sp., Nannochloropsis sp., Thalassiosira sp., Chaetoceros sp. and Pavlova sp. (Guedes et al., 2015; Rasdi and Qin, 2015).

Microalgae, including microalgae paste can be used to enrich live food organisms to directly improve the fatty acid composition in live food such as Moina (Mendez-Martinez et al., 2018). As reported in prior research, the important nutrients in larvae enrichment including critical Polyunsaturate Fatty Acid (PUFAs of EPA and DHA) and most microalgae composition are rich either in one or both fatty acids (Rasdi and Qin., 2016a, b; Ahmad et al., 2018). The specific growth rate of Moina macrocopa and Moina micrura increased when fed on three different algae, namely Pseudokirchneriella subcapitta, Monoraphidium minutum and Desmodesmus armatus, and carbon content of these algal species varied between 42.05 and $49.3 \%$ dry weight, phosphorus content ranged between $0.04 \%$ and $0.20 \%$ and nitrogen content ranged between $6.7 \%$ and $7.7 \%$ (Bouchnak et al., 2014) such that these algae can provide improved nutrition for Moina water flea species.

Studies by Nandini et al. (2004) proved that production of Moina offspring was frequent and fecundity was high when fed on microalgae diet of Chlorella with lipid accumulation of up to $85 \%$ of biomass (Blazencic, 2007; Kumar et al., 2017). Chlorella contains proteins, polysaccharides, minerals, antioxidants, carotenoids, lipids, immune stimulator compounds as well as vitamins (Sharma et al., 2012; Maliwat 2017). While microalgae provide good nutrition for cladocerans, other research has shown that application of vitamin to the cultivation of algae used as food for zooplankton has contributed to a major rise in the production of zooplankton species for instance in Moina micrura where faster growth was achieved when fed on algae with vitamin (B vitamin complex) additives (Sipauba et al., 2002).

Other than microalgae, artificial diets including rice bran, yeast, oil emulsion, chicken and cow manures have been used to enrich cladoceran culture media. Rice bran and cassava bran is an artificial diet that has been directly used in Moina feeding, typically processed into a suspension of small particles (Mubarak et al., 2017). Rice bran is a suitable feed for Moina as it provides multiple nutrients and sources of energy, such as protein (12$13 \%$ ), lipid (16-205), linoleic acid (6.35-6.85\%), acid a- linolenate (0.2-0.27\%), vitamin B and minerals (6 - 9\%) (Faria et al., 2012; Murtaza et al., 2011; Mubarak et al., 2017). Cassava bran (Manihot utilisima) also contain nutrients including carbohydrates (56 - 94\%), Vitamin B1 (thiamin) $\left(2.16-48 \mu \mathrm{g} \mathrm{g}^{-1}\right)$ and Vitamin C $\left(50-510 \mu \mathrm{g} \mathrm{g}^{-1}\right)$, with low protein content $(1.5-4.7 \% 0$, lipid $(0.3$ $3.2 \%)$ and lower mineral content as compared to rice bran (Salvador et al., 2014; Faria et al., 2012; Mubarak et al., 2017). Enrichment of live food culture media with rice bran showed higher levels of RNA, DNA, amino acid and protein such as in cultured Moina than with cassava bran enrichment (Mubarak et al. , 2017).

Oil emulsions from canola oil, squid oil, etc., are also using to boost composition of fatty acids of Moina while essential fatty acids also foster other cladoceran development (MullerNavarra, 1995; Loh et al., 2013). Loh et al., (2012) demonstrate low essential fatty acids in unenriched Moina (DHA, AA, EPA) and the lipid level improved when culture media was enriched with canola and squid oil (. Enrichment of Moina with carotenogenic yeast improved carotenoid content and it has been concluded that the enriched Moina can be supplied to cultured fish, as fish cannot synthesize carotenoids like other animals (Kushniryk et al., 2015).

Since this cladocerans species can tolerate poor water conditions, both organic and inorganic manures can be used for culturing Moina. Previous study by Golder et al. (2007) reported human urine, animal urine, chicken manure, poultry droppings, and cattle dung may all be used to produce zooplankton due to their indirect roles as organic fertilizers. The use of organic fertilizers or manure in aquaculture is an efficient and economical means of increasing production in aquaculture ponds (Rahman et al., 2003). A study by Loh et al. (2009), demonstrated that Moina macrocopa, fed with fish feces resulted in higher reproductive rates within shorter generation times such that a greater number of neonates could be produced. Moina micrura showed a high intrinsic increase when cultured in poultry droppings, and the results showed positive effects of organic fertilization in providing a nourishing quality of water which improved production of zooplankton (Hyppolite et al., 2014). When cultured on poultry 
manure, Moina may have acquired a high amount of n-3 HUFA directly from the manure or, indirectly, from algae and other fertilizer-induced microorganisms (Alam et al., 1993; Rahman et al., 2003). Large production of cladocerans resulted from culture in chicken manure fertilizer medium. Indeed, Moina cultured with fish waste materials also contained higher nutritional value including HUFA levels and, it was concluded that the available nutrients could provide better growth performance of shrimp and fish larvae at early stages (Loh et al., 2016).

Pathogen-free organic waste product as feed for rearing cladocerans : Moina can generally adapt to poor water quality (Rottman et al., 2014) which is of significant characteristic. Under varying conditions, they can be cultivated quickly, even in conditions with low oxygen and heavy ammonium content as reported by Sarma et al. (2003). The characteristics of superior adaptable to environmental conditions, their survival in a deficient oxygen environment has been enhanced by Moina ability to synthesize haemoglobin (Samuel, 2014). Being hardy in quite extreme condition, Moina have also been used in toxicity testing (Mangas-Ramirez et al., 2002; Nandini et al., 2004). Beside extreme parameters, it is recognized that the cladoceran grows optimally at $25-30^{\circ} \mathrm{C}$ (Lampert and Sommer, 1997; Nandini et al., 2004) with pH ranging between 6.5 - 9.5 (Rahman et al., 2003). Being a microscopic and filter feeder; bacteria, yeast, phytoplankton and detritus (decaying organic matter) Moina are known to feed on different species. Due to this advantage, Moina can be cultured on animal, agricultural and food industry waste as feed (Patil et al., 2010; Mubarak et al., 2017). Cow dung, fish faces, horse manure, rice bran, chicken dropping and mineral fertilizers were found to support successful mass culture of cladocerans (Punia et al., 1988; Rottman et al., 2014; Loh et al., 2009; Okunsebor et al., 2012; Budhin et al., 2016; Rasdi et al., 2018c). As cladocerans are considered for many fish and shrimp larvae as live feed, they have been mass cultured successfully by many researchers, who have been able to use a variety of cheap feed, organic and waste products (Golder et al., 2007; Shrivastava et al., 2006; Sivakumar, 2005; Suresh Kumar, 2000; Kareem et al., 2010). The density of Moina's also increases quickly as there are sufficient number of yeast, bacteria and phytoplankton (Rottman et al., 2014). Hence, finding an appropriate feed in large amount is required to ensure continuous production of Moina for sustainable aquaculture production all year round. The use of pathogen-free poultry waste is of considerable importance to avoid potential transmission of pathogens to planktons, as well as to humans by microbially infected poultry services fed by fish (Adewunmi et al., 2011). The organic fumes were treated to ensure their hygienic state by steam cooking, cooked-oven drying, sun-dried and roasted dried methods before application in aquaculture to ensure pathogenfree fish and shellfish production (Nwabueze, 2011).

Improving Moina cultivation by feed manipulation: Moina can be developed from affordable, restorative waste products (Loh et al., 2013). In Singapore, Moina micrura has been grown in ponds fertilized with chicken and pig manures as the means of feeding (Rottman et al., 2014). In India, Moina has been successfully cultivated by the application of both organic manures and inorganic fertilizers as culture media (lyiola, 2018). However, the availability of Moina in natural environment is seasonal and therefore, it is always necessary to develop culture technology for Moina in order to maintain their availability (Armin et al., 2014).

By manipulating the quality and quantity of feed, Moina population density can be increased by increasing its fecundity and, by decreasing the reproductive period (Hakima et al., 2013; Mubarak et al., 2017). Previous study showed an increase in density of Moina to 15,000-20,000 individual ${ }^{-1}$ when fed on

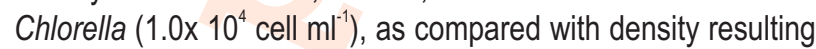
from enrichment with animal waste; fowl and cow manure $(1,301$ individual $\mathrm{I}^{-1}$ ). Nutritional content of Moina feed also plays an essential role in maintaining sustainable development and survival of the continuous culture for generations rotein, fatty acids and amino acids concentrations of feed directly affects the population growth and fecundity of Moina (Mubarak et al., 2017). The endocrine system and reproduction of Moina were also affected by amino acid and arginine levels in media provided for their growth and development (Jobgen et al., 2006; Mubarak et al., 2017). It was identified that arginine and histidine can increase population growth rate, induce resting egg production and enhance reproduction rate (Koch et al., 2011; Fink et al., 2011; Bouchnak et al., 2014). Moreover, glycine, tyrosine, phenylalanine and lysine levels were seen to affect the speed of embryo development in the incubating cavity (Li et al., 2008; Mubarak et al., 2017).

Moina can be cultured by mass culture, semi-continuous culture or batch culture method. Batch culture method permits control of daily production of Moina and is particularly applicable when a specific amount of Moina is needed (Rottman et al., 2014). Moina is collected fully from 5 to 10 days after inoculation, and the colony is restarted again. The batch process is useful for preserving Moina's pure cultures, since there are limited risks that the sample may get tainted with contaminants (Rottman et al., 2014). Semi-continuous cultivation with partial daily harvest of produced Moina can be sustained for two months. Exchange of water and daily feeding will hold the population in a state of rapid increase and development in Moina (Rottman et al., 2014).

This review highlights the importance of using Moina as live feed organisms in the aquaculture industry and that the enrichment of Moina is required in order to meet the adequate nutrient supply for fish and shrimp larvae to enhance their growth performance. It has been concluded that Moina meets the requirement of a suitable candidate for live feed applications. Moina was selected as live feed sources for larval crops due to their nutritional value and low production costs as feeding medium. High protein levels, essential and non- amino acids and 
HUFAs have been recorded in Moina. Moreover, Moina can be easily maintained through mass culture as they can tolerate poor water quality. Also, Moina has been successfully enriched for improved nutritional value by various feeding methods. Thus, this review reflects that Moina has strong potential as a live feed organism for larvae and shrimp production.

\section{Acknowledgment}

The writing of this review article was supported by the Fundamental Research Grant Scheme (FRGS) provided by Ministry of Higher Education Malaysia under grant Vote No. 59530 , in order to generate new ideas and methodology for the development of live food nutrition in Malaysian aquaculture industry. Contribution to the reviews by researchers from other institutions are greatly appreciated.

\section{References}

Abbas, M.F., S.D. Salman and S.H. Al Mayahy: Diversity and seasonal changes of zooplankton communities in the Shatt Al-Arab River, Basrah, Iraq, with a special reference to Cladocera. Int. J. Mar. Sci., 5, 1-14 (2015).

Adewunmi, A.A., I.K. Adewunmi and V.F. Olaleye: Livestock wastemenace: Fish wealth-solution. Afr. J. Environ. Sci. Technol., 5, 149$154(2011)$

Adeyema, A.A., G.A. Oladosu and A.O. Ayinla: Growth and survival of fry of African catfish species, Claria gariepinus (Burchell), Heterobrachus bidorsalis (Geoffrey) and Heteroclarias reared on Moina dubia in comparison with other first feed sources. Aquaculture, 119, 41-45 (1994).

Agadjihouede, H., E. Montchowui, S.A. Montcho, C.A. Bonou and P.A. Laleye: Growth and development of three species of the zooplankton (Brachionus calyciflorus, Moina micrura and Thermocyclops sp.) breeding on poultry dropping in mixed condition in tanks. Int. J. Fisher. Aqu. Stud., 2, 189-196 (2014).

Ahmad, M.T., M. Shariff, F. Md. Yusoff, Y.M. Goh and S. Banerjee: Applications of microalga Chlorella vulgaris in aquaculture. Reviews in Aquaculture (2018).

Akbary, P., M. Imanpoor, M. Sudagar and N.M. Makhdomi: Comparison between live food and artificial diet on survival rate, growth and body chemical composition of Oncorhynchus mykiss larvae. Iran. J. Fisher. Sci., 9, 19-32 (2010).

Alam, M.J., K.J. Ang, S.H. Cheah, M.A. Ambak and C.R. Saad: Effects of Moina micrura (Kurz) from two different culture sources as a replacement of Artemia spp. in production of Macrobrachium rosenbergii (de Man) postlarvae. Aquac. Res., 24, 47-56 (1993).

Alonso, M., A.N. Neretina, L.O. Sanoamuang, N. Saengphan and A.A. Kotov: A new species of Moina Baird, 1850 (Cladocera: Moinidae) from Thailand. Zootaxa, 4554, 199-218 (2019).

Altaff, K. and M.U.D. War: Culture of Ceriodaphnia cornuta, using chicken manure as fertilizer: Conversion of waste product into highly nutritive animal protein. Biolog. Sci.- Pak. J. Sci. Indus. Res., 53, 89-91 (2010).

Amornsakun, T., W. Sriwatana and P. Promkaew: Some aspects in early life stage of Snake head fish, Channa striatus larvae. Songklan. J. Sci. Technol, 26, 347-356 (2011).

Coronado, A.S., M. Vivian and C. Camacho: Influence of yeast, chicken manure and daily feeding of Chlorella ellipsoidea in the population growth of Moina micrura. PUP J. Sci Tech., 7, 18-27 (2014).

Balayla, D.J. and B. Moss: Relative importance of grazing on algae by plant associated and open water microcrustacea (Cladocera). Arch. Hydrobiol., 161, 199-224 (2004).

Bekker, E.I., D.P. Karabanov, Y.R. Galimov and A.A. Kotov: DNA barcoding reveals high cryptic diversity in the North Eurasian Moina species (Crustacea: Cladocera). PloS ONE, 11, e0161737. (2016).

Bouchnak, R. and C.E. Steinberg: Algal diets and natural xenobiotics impact energy allocation in cladocerans. II. Moina macrocopa and Moina micrura. Limnol., 44, 23-31. (2014).

Bogut, I., Z. Adamek, Z. Puškadija and D. Galović: Nutritional value of planktonic cladoceran Daphnia magna for common carp (Cyprinus carpio) fry feeding. Croat. J. Fisher.: Ribar., 68, 1-10 (2010).

Brown, M.R., S.W. Jeffry, J.K. Volkman and G.A. Dunstan: Nutritional properties of microalgae for mariculture. Aquaculture, 151, 315331 (1997)

Bryant, P.L. and A.J. Matty: Optimization of Artemia feeding rate for carp (Cyprinus carpio L.). Aquaculture, 21, 203-212 (1980).

Gogoi, B., V. Safi and D.N. Das: The Cladoceran as live feed in fish culture: A brief review. Res. J. Ani., Veter. Fish. Sci., 4, 7-12 (2016).

Cheikyula, J.O. and P.O. Ofojekwu: Growth responses and survival of the goldfish, Cassasius austrattus (Cyprinidae) fry reared on Moina (Cladocera) and Cylops (copepod). J. Aqu. Sci., 18, 43-46 (2003).

Dararat, W., K. Lomthaisong and L.O. Sanoamuang: Biochemical composition of three species of fairy shrimp (Branchiopoda: Anostraca) from Thailand. J. Crust. Biol., 32, 81-87 (2012).

Das, S.K., V.K. Tiwari, G. Venkateshwarlu, A.K. Reddy, J. Parhi, P. Sarma and J.K. Chettri: Growth, survival and fatty acid composition of Macrobrachium rosenbergii (de Man, 1879) post larvae fed HUFAenriched Moina micrura. Aquaculture, 269, 464-475 (2007).

de Freitas Côrtes, G., M.Y. Tsuzuki and E.M.C. Melo: Monoculture of the ciliate protozoan Euplotes sp. (Ciliophora; Hypotrichia) fed with different diets. Acta Scienti. Biol. Sci., 35, 15-19 (2013).

Dumont, H.J., A.C. Rietzler and K. Kalapothakis: Micromoina arboricola n. gen., n. spec. (Crustacea: Cladocera), a new moinid living in a forest tree-hole in Minas Gerais, Brazil. Zootaxa, 3652, 533-546 (2013).

Dwivedi, S.N., A.K. Reddy and K.B. Sreeramamurty: A new method for mass culture of Branchionus plicatilis, Geobios New Reports, 4, 54056 (1985).

Dwivedi, S.N., S.K.R. Ansari and M.Q. Ahmed: Mass culture of brine shrimp under controlled conditions in cement pools at Bombay, India. In: The brine shrimp, Artemia (Eds.: G. Persoone, P. Sorgeloos, O. Roels and E. Jaspers). Universal Press Western, Belgium, Vol.3, pp. 175-183 (1980).

Faria, S., P. Bassinello and M. Penteado: Nutritional composition of rice bran submitted to different stabilization procedures. Brazilian J. Pharmac. Sci., 48, 35-45 (2012)

Fernando, C.H.A.: Guide to Tropical Freshwater Zooplankton. Backhuys, Leiden. (2002).

Fink, P., C. Pflitsch and K. Marin: Dietary essential amino acids affect the reproduction of the keystone herbivore Daphnia pulex. PLoS ONE, 6, e28498 (2011)

FRSS: Fisheries statistical yearbook of Bangladesh. Department of Fisheries, Dhaka, Bangladesh (2005).

Gama-Flores, J.L., M.E. Huidobro-Salas, S.S.S. Sarma, S. Nandini, R. Zepeda-Mejia and R.D. Gulati: Temperature and age affect the life 
history characteristics and fatty acid profiles of Moina macrocopa (Cladocera). J. Ther. Biol., 53, 135-142 (2015).

Golder, D., S. Rana, S.D. Paria and B.B. Jana: Human urine is an excellent liquid waste for the culture of fish organisms Moina micrura. Ecol. Engin., 4, 326-332 (2007).

Guedes, A.C., I.S. Pinto and F.X. Malcata: Application of microalgae protein to aquafeed. In: Handbook of Marine Microalgae. Academic Press, pp. 93-125 (2015).

Hakima, B., C. Khemissa and S. Boudjema: Effects food limitation on the life history of Simocephalus expinosus (Cladocera: Daphniidae). J. Biol. Sci., 5, 25-31 (2013).

Heine-Fuster, I., C.V. Retter, P. Sabat and R.R. Jiliberto: Osmoregulatory and demographic responses to salinity of the exotic cladoceran Daphnia exilis. J. Plank. Rese., 32, 1405-1411 (2010).

Hudson, J.J., W.D. Taylor and D.W. Schindler: Planktonic nutrient regeneration and cycling efficiency in temperate lakes. Nature, 400, 659-661 (1999).

lannacone, J.A. and L. Alvarino: Cnironomus calligrapghus Goeldi y Moina macrocopa (Sars) como herramientas ecotoxicologicas para la evaluacion del lindano y clorpirifos. Bol. Soc. Biol. Concepcion (Chile), 73, 33-39 (2002).

Islam, M., M. Hassan, M. Begum, N. Punom, M. Begum and N. Sultana: Effects of feeding zooplankton, Moina macrocopa (Straus, 1820) on the growth of Nile tilapia Oreochromis niloticus L. Bangl. J. Scient. Indu. Res., 52, 81-88 (2017).

Iyiola, A.O.: Zooplankton production in the presence of different manures in culture system. J. Agricult. Ecol. Res. Inter., 16, 1-8 (2018).

Jobgen, W.S., S.K. Fried, W.J. Fu, C.J. Meininger and G. Wu: Regulatory role for the arginine nitric oxide pathway in metabolism of energy substrates. J. Nutr. Biochem., 17, 571-588 (2006).

Kamrunnahar, K., M. Anisuzzaman, J.U. Cheol and S.J. Kang: Mass culture of Moina macrocopa using organic waste and its feeding effects on the performance of Pagrus major larvae. Egypt. J. Aqu. Res., 45, 75-80 (2019).

Kanazawa, A.: Nutrition of marine fish larvae. J. Appl. Aquac., 13, 103$143(2003)$

Kar, S., P. Das, U. Das, M. Bimola, D. Kar and G. Aditya: Culture of the zooplankton as fish food: Observations on three freshwater species from Assam, India. Aquac. Aqu. Conser. Legisl., 10, 12101220 (2017).

Karlsen, Ø., T. van der Meeren, I. Rønnestad, A.M. Jensen, T.F. Galloway, E. Kjørsvik and K. Hamre: Copepods enhance nutritional status, growth and development in Atlantic cod (Gadus morhua L.) larvae - can we identify the underlying factors? Peer J., 3, e902 (2015).

Khudyi, O., O. Kushniryk, L. Khuda and M. Marchenko: Differences in nutritional value and amino acid composition of Moina macrocopa (Straus) using yeast Saccharomyces cerevisiae and Rhodotorula glutinis as fodder substrates. Inter. Lett. Nat. Sci., 68, 27-34 (2018).

Kim, D., T.S. Kim, H.D. Ryu and S.I. Lee: Treatment of low carbon-tonitrogen waste water using two-stage sequencing batch reactor with independent nitrification. Process. Biochen., 43, 406-413 (2008).

Koch, U., D.M. Creuzburg, H.P. Grossart and D. Straile: Single dietary amino acids control resting egg production and affect population growth of a key fresh- water herbivore. Oecologia, 167, 981-989 (2011).

Kolkovski, S.: Digestive enzymes in fish larvae and juveniles - implications and applications to formulated diets. Aquacult., 200, 181-201 (2001).

Kotani, T., H. Imari, A. Miyashima and H. Fushimi: Effects of feeding with frozen freshwater cladoceran Moina macrocopa on the performance of red sea bream Pagrus major larviculture. Aquacult. Inter., 24, 183-197 (2016).

Kumar, S.D., P. Santhanam, S. Ananth, M. Kaviyarasan, P. Nithya, B. Dhanalakshmi and M.K. Kim: Evaluation of suitability of wastewater-grown microalgae (Picochlorum maculatum) and copepod (Oithona rigida) as live feed for white leg shrimp Litopenaeus vannamei post-larvae. Aquac. Inter., 25, 393-411 (2017).

Kushniryk, O., O. Khudyi, L. Khuda, R. Kolman and M. Marchenko: Cultivating Moina macrocopa Straus in different media using carotenogenic yeast Rhodotorula. Arch. Pol. Fisher., 23, 37-42 (2015).

Lampert, W. and U. Sommer: Limno-ecology: The ecology of lakes and streams. Oxford University Press, pp. 387 (1997).

Lavens, P. and P. Sorgeloos: Manual on the production and use of live food for aquaculture. FAO Fish. Tech. Paper No. 361, pp. 295 (1996).

Leitao, J., R. Ribeiro, A.M. Soares and I. Lopes: Tolerance to copper and to salinity in Daphnia longispina: implications within a climate change scenario. PloS ONE, 8, e68702 (2013).

Li, P., K. Mai, J. Trushenski and G. Wu: New developments in fish amino acid nutrition: towards functional and environmentally oriented aquafeeds. Amino Acid, 37, 43-53 (2008).

Li, Y., P. Xie, J. Zhang, M. Tao and X. Deng: Effects of filter-feeding planktivorous fish and cyanobacteria on structuring the zooplankton community in the eastern plain lakes of China. Ecolog. Engin., 99, 238-245 (2017).

Lim, L.C., P. Dhert and P. Sorgeloos: Recent developments in the application of live feeds in the freshwater ornamental fish culture. Aquaculture, 227, 319-331 (2003).

Lim, R.P., M.F. Abdullah and C.H. Fernando: Ecological studies of Cladocera in the ricefields of Tanjung Karang, Malaysia, subjected to pesticide treatment. Hydrobiologia, 113, 99-103 (1984).

Loh, J.Y., C.W. How, Y.S. Hii, G. Khoo and H.K.A. Ong: Fish faeces as a food source for cultivating the water flea, Moina macrocopa potential. J. Sci. Technol. Trop., 5, 5-9 (2009).

Loh, J.Y. and G. Khoo: The effects of recirculating aquaculture system effluent water on growth of Moina macrocopa (Straus). Int. J. Zool. Stu., 1, 01-08 (2016).

Loh, J.Y., H.K.A. Ong, Y.S. Hii, T.J. Smith, M.W. Lock and G. Khoo: Highly unsaturated fatty acid (HUFA) retention in the freshwater cladoceran, Moina macrocopa, enriched with lipid emulsions. The Israeli J. Aquacult. Bamidgeh, 64, 1-9 (2012).

Loh, J.Y., H.K.A. Ong, Y.S. Hii, T.J. Smith, M.M. Lock and G. Khoo: Impact of potential food sources on the life table of the cladoceran, Moina macrocopa. Bamidgeh, IJA_65.2013.820, 1 -8 (2013).

Maliwat, G.C., S. Velasquez, J.L. Robil, M. Chan, R.F. Traifalgar, M. Tayamen and J.A. Ragaza: Growth and immune response of giant freshwater prawn Macrobrachium rosenbergii (De Man) postlarvae fed diets containing Chlorella vulgaris (Beijerinck). Aquaculture res., 48, 1666-1676 (2017).

Mangas-Ramirez, E., S.S.S. Sarma and S. Nandini: Combined effects of algal (Chlorella vulgaris) density and ammonia concentration on the population dynamics of Ceriodaphnia dubia and Moina macrocopa (Cladocera). Ecotoxicol. Environ. Saf., 51, 216-222 
(2002)

Mayer, C.M. and D.H. Wahl: The relationship between prey selectivity and growth and survival in larval fish. Can. J. Fish. Aquat. Sci., 54, 1504-1512 (1997).

Méndez-Martínez, Y., M.U. García-Guerrero, M.C. Lora-Vilchis, L.R. Martínez-Córdova, F.G. Arcos-Ortega, J.J. Alpuche and E. CortésJacinto: Nutritional effect of Artemia nauplii enriched with Tetraselmis suecica and Chaetoceros calcitrans microalgae on growth and survival on the river prawn Macrobrachium americanum larvae. Aquac. Inter., 26, 1001-1015(2018).

Miah, M.F., S. Roy, E. Jinnat and Z.K. Khan: Assessment of Daphnia, Moina and Cylops in freshwater ecosystems and the evaluation of mixed culture in laboratory. Am. Int. J. Res. Form Appl. Nat. Sci., 3, 1-7 (2013).

Mona, M., M.E. Gamal, F.A. Razek and M.N. Eldeen: Utilization of Daphnia longispina as supplementary food for rearing Marsupenaeus japonicus post larvae. J. Mar. Biol. Assoc. India, 59,74 (2017).

Mubarak, A.S., D. Jusadi, M.Z. Junior and M.A. Suprayudi: The population growth and the nutritional status of Moina macrocopa feed with rice bran and cassava bran suspensions. J. Akuak. Indon., 16, 223-233 (2017).

Muller Navrras, D.C.: Evidence that a highly unsaturated fatty acid limits Daphnia growth in nature. Arch. Hydribiol., 132, 297-307 (1995).

Murtaza, A.S., A. Khawar and S. Naheed: Effect of processing on nutritional value of rice (Oryza sativa). J. Med. Sci., 6, 68-73 (2011).

Nandini, S., M. Mayeli and S.S.S. Sarma: Effects of stress on the lifetable demography of Moina macrocopa. Hydrobiologia, 526, 245254 (2004).

Nandini, S., R.A. Soto and S.S.S. Sarma: Growth of Plankton (Scenedesmus acutus (Chlorophyceae) and Moina macrocopa (Cladocera)) on domestic wastewater. CLEAN-Soil, Air, Water, 41, 11-15(2013)

Ngupula, G.W., A.P. Shoko, M. Musiba, J. Ndikumana and E. Zziwa: Performance of Artemia shell-free embryos, Moina micrura and phytoplankton on larvae of reared African catfish. Afr. Crop Sci. J., 22, 875-881 (2014).

Nwabueze, A.A.: Evaluation of methods of processing pathogen-free poultry droppings for fish-cum poultry culture. Inter. J. Sci. Nat., 2, 796-798. (2011)

Oh, S. and K. Choi: Optimal conditions for three brood chronic toxicity test method using a freshwater macroinvertebrate Moina macrocopa. Environ. Monit. Assess., 184, 3687-3695 (2012).

Okunsebor, S.A. and P.C. Ofojekwu: Mass production of Moina micrura through manipulation of concentration, combinations of manure and period of growth in laboratory. Euro. J. Scie. Res., 83, 576-589 (2012)

Okunsebor, S.A. and V. Ayuma: Growth, survival rate and condition factor of Heteroclarias hatchlings fed cultured Moina micrura, shell free Artemia and combination of both as starter feed. Fisher. Soc. Nige., 2010, 519-525(2010)

Olivotto, M., I. Cardinali, L. Barbaresi, F. Maradonna and O. Carnevali: Coral reef fish breeding: The secrets of each species. Aquaculture, 224, 69-78 (2003).

Olurin, K. and A. Oluwo: Growth and survival of African catfish (Clarias gariepinus) larvae fed decapsulated Artemia, live Daphnia, or commercial starter diet. The Israeli J. Aquac. Bamidgeh, 62, 2010, 50-55(2010)

Parakrama, M.G.I.S., K.D. Rawat, G. Venkateshwarlu and A.K. Reddy:
Supply of Astaxanthin and its combinations through live feed (Moina micrura) enrichment affects the growth, survival and fatty acid profile of Macrobrachium resenvergiilarvae. J. Nati. Aqu. Res. Res. Develop. Age. Sri Lanka, 41, pp. 44-58 (2012).

Paranhos, J.D.N., V.L.S. Almeida, J.P. Silva Filho, M.N. Paranaguá, M.M. Júnior and S.N. Leitão: The zooplankton biodiversity of some freshwater environments in Parnaíba basin (Piauí, Northeastern Brazil). Braz. J. Biol., 73, 125-134 (2013).

Parisi, G., G. Terova, L. Gasco, G. Piccolo, A. Roncarati, V.M. Moretti and A. Pais: Current status and future perspectives of Italian finfish aquaculture. Rev. Fish Biol. Fisher., 24, 15-73 (2014).

Patil, S.S., A.J. Ward, M.S. Kumar and A.S. Ball: Utilising bacterial communities associated with digested piggery effluent as a primary food source for the batch culture of Moina australiensis. Bioso. Technol., 97, 109-116 (2010).

Pronob, D., S.C. Mandal, S.K. Bhagabati, M.S. Akhtar and S.K. Singh: Important live food organisms and their role in aquaculture. In.: Frontiers in Aquaculture (Ed.: M. Sukham). Narendra Publishing House, pp. 69-86. (2012).

Punia, P.: Culture of Moina micrura on various organic waste products. J. Indian Fish. Associ., 18, 129-134 (1988).

Qin, J.G. and D.A. Culver: Effect of larval fish and nutrient enrichment on plankton dynamics in experimental ponds. Hydrobiologia, 321, 109-118 (1996).

Rahman, S.M., M.N. Siddiqui, M.N. Haque, M.A. Rouf, M.A. Bari and M.A.H. Christy: Culture techniques of Moina species with organic and inorganic fertilizers. Khul. Univer. Stud., 5, 21-25 (2003).

Rasdi, N.W. and J.G. Qin: Effect of N : P ratio on growth and chemical composition of Nannochloropsis oculata and Tisochrysis lutea. J. App. Phycol., 27, 2221-2230 (2015).

Rasdi, N.W. and J.G. Qin: Improvement of copepod nutritional quality as live food for aquaculture: A review. Aquac. Res., 47, 1-20 (2016a).

Rasdi, N.W., J.G. Qin and Y. Li: Effects of dietary microalgae on fatty acids and digestive enzymes in copepod Cyclopina kasignete, a potential live food for fish larvae. Aquac. Res., 47, 3254-3264 (2016b).

Rasdi, N.W. and J.G. Qin: Copepod supplementation as a live food improved growth and survival of Asian seabass Lates calcarifer larvae. Aquacult. Res., 49, 3606-3613 (2018b).

Rasdi, N.W. and J.G. Qin: Impact of food type on growth, survival and reproduction of the cyclopoid copepod Cyclopina kasignete as a potential live food in aquaculture. Aquac. Inter., 26, 1281-1295 (2018a).

Rasdi, N.W., H. Suhaimi, A. Yuslan, Y.Y. Sung, M. Ikhwanuddin, S.S. Omar, J.G. Qin, Z. Kassim and F.M. Yusoff: Effect of mono and binary diets on growth and reproduction of cyclopoid copepod. Aquac. Aquar. Conser. Legisl, 11, 1658-1671 (2018c).

Rasdi, N.W. and J.G. Qin: Toleration of Moina sp. towards salinity and food types as the prominent factors in determining Moina sp. abundance: A review. Res. Review. J. Agric. Allied Sci.,7, 35 - 40 (2018d).

Rasdi, N.W., H. Suhaimi, A. Hagiwara, M. Ikhwanuddin, M.A. Ghaffar, A. Yuslan and S. Najuwa: Effect of different salinities gradient on fatty acid composition, growth, survival and reproductive performance of Moina macrocopa (Straus 1820) (Crustacean, Cladocera) (2019). doi: 10.20944/preprints201906.0205.v1

Ricardo, C.D.: A program on growing food organisms for Leyte Freshwater Fish Hatchery Babatngon, Leyte, Philippines. Training Course on Growing Food Organisms for Fish hatcheries. pp. 23-24 (1981). 
Rimmer, M.A., K. Williams, N. Giri, R. Knuckey and A. Reynolds: Improved hatchery and grow-out technology for marine finfish aquaculture in the Asia-Pacific region. Final Report Number: FR2011-32. ISBN: 978192196229 5. ACIAR, Canberra. (2011).

Rizo, E.Z.C., Y. Gu, R.D.S. Papa, H.J. Dumont and B.P. Han: Identifying functional groups and ecological roles of tropical and subtropical freshwater Cladocera in Asia. Hydrobiologia, 799, 83-99 (2017).

Rodolfo, F.V. and M.E. Edmundo: Preliminary studies on Moina sp. Production in freshwater tanks. Aquaculture, 21, 93-96 (1980).

Rønnestad, I., M. Yúfera, B. Ueberschär, L. Ribeiro, Ø. Saele and C. Boglione: Feeding behaviour and digestive physiology in larval fish: Current knowledge, and gaps and bottlenecks in research. Rev. Aquacult., 5, S59-S98 (2013).

Rottmann, R.W., J.S. Graves, C. Watson and R.P.E. Yanong: Culture techniques of Moina: The ideal Daphnia for feeding freshwater fry. University of Florida. CIR 1054, FAO, Rome, pp. 2-9 (2014).

Saini, V.P., M.C. Gupta, L.L. Sharma and M.L. Ojha: Efficacy of split dose application in the mass culture of cladocerans using domestic sewage. Eco. Env. Cons., 19, 265-269 (2013).

Salvador, E.M., V. Steenkamp and C.M. McCrindle: Production consumption and nutritional value of cassava Manihot utilisina in Mozambique: review. J. Agric. Biotechnol. Sustain. Devel., 6, 2938 (2014).

Samir, M. and S. Banik: Production and application of live food organisms for freshwater ornamental fish larviculture. Adv. Biores., 6, 159167 (2015).

Sargent, J., I. McEvoy, A. Estevez, G. Bell, M. Bell, J. Henderson and D. Tocher: Lipid nutrition of marine fish during early development: current status and future directions. Aquaculture, 179, 217-229 (1999).

Sarma, S.S., E.M. Ramirez and S. Nandini: Effect of ammonia toxicity on the competition among three species of cladocerans (Crustacea: Cladocera). Ecotoxicol. Environ. Saf., 55, 227-235 (2003).

Sharma, R., G.P. Singh and V.K. Sharma: Effects of culture conditions on growth and biochemical profile of Chlorella vulgaris. J. Plant Pathol. Microbiol., 3, 131 (2012).

Shirgur, G.A.: Observations on rapid production of zooplankton in fish nurseries by intensive phased manuring. J. Indian Fish. Assoc., 1, 25-50. (1971).

Shrivastava, A., R.M. Rathore and R. Chakrabarthi: Effects of four different doses of organic manures in the production of Ceriodaphnia cornuta. Biores. Technol., 97, 1036-1040 (2006).

Sinev, A.Y. and F.M. Yusoff: New data on Cladocera (Crustacea: Branchiopoda) of Sabah State, Borneo Island, Malaysia. Zootaxa, 4438, 362-372 (2018).

Singh, K., S. Munilkumar, N.P. Sahu, A. Das and G.A. Devi: Feeding HUFA and vitamin C-enriched Moina micrura enhances growth and survival of Anabas testudineus (Bloch, 1792) larvae. Aquaculture, 500, 378-384 (2019).

Singh, S.K., U. Mishra and S.D. Roy: Effect of feeding enriched formulated diet and live feed on growth, survival and fatty acid profile of Deccan Mahseer, Tor Khudree (Sykes) first feeding fry. J. Aquac. Res. Devel., 3, 1-6 (2012).

Sipaúba-Tavares, L.H. and M.A. Bachion: Population growth and development of two species of Cladocera, Moina micrura and Diaphanosoma birgei, in laboratory. Brazilian J. Biol., 62, 701-711 (2002)
Sipaúba-Tavares, L.H., B.S. Truzzi and F.D.A. Berchielli-Morais: Growth and development time of subtropical Cladocera Diaphanosoma birgei Korinek, 1981 fed with different microalgal diets. Brazilian J. Biol., 74, 464-471. (2014).

Solomon, I.O. and S.O. Ovie: Moisture, protein, and amino acid contents of three freshwater zooplankton used as feed for aquaculture larvae and postlarvae. The Israeli J. Aquac., 58, 29-33 (2006).

Srivastava, A., R.M. Rathore and R. Chakrabarthi: Effects of four different doses of organic manures in the production of Ceriodaphnia cornuta. Biores. Technol., 97, 1036-1040 (2006).

Taghavi, D., O. Farhadian, N.M. Soofiani and Y. Keivany: Effects of different light/dark regimes and algal food on growth, fecundity, ephippial induction and molting of freshwater cladoceran, Ceriodaphnia quadrangula. Aquaculture, 410, 190-196 (2013).

Tawaratmanikul, P., T. Viputanimat, A. Mewan and K. Pokasap: Study on the Suitable Moina density in Nursing the Giant Catfish, Pangasianodon gigas. Technical Paper No. 6/1988, Thailand: Pathumthani Freshwater Fisheries Station, Inland Fisheries Division, Department of Fisheries, Ministry of Agriculture and Cooperatives, 6 (in Thai with English abstract) (1988).

Tong, S.Y., C.H. Liu and X.T. Wang: Appraisement and analysis of nutrient composition for Moina mongolica Daddy. J. Dalian Fish. Univ., 11, 29-33 (1988).

Valdez-Moreno, M., N.V. Ivanova, M.E. Gutierrez, S.L. Pedersen, K. Bessonov and P.D. Hebert: Using eDNA to biomonitor the fish community in a tropical oligotrophic lake. PloS ONE, 14, e0215505. (2019).

Velasco, S.Y. and S.W. Corredor: Nutritional requirements of freshwater ornamental fish: A review. Rev. MVZ Cordoba, 16, 2458-2469 (2011).

Vignatti, A.M., G.C. Cabrera and S.A. Echaniz: Distribution and biological aspects of the introduced species Moina macrocopa (Straus, 1820) (Crustacea, Cladocera) in the semi-arid central region of Argentina. Biota Neotropica, 13, 86-92 (2013).

Villamizar, N., A.G. Alcazar and F.J. Sánchez-Vázquez: Effect of light spectrum and photoperiod on the growth, development and survival of European sea bass (Dicentrarchus labrax) larvae. Aquaculture, 292, 80-86 (2009).

Wang, Z., C. Yan and R.V. Hyne: Effects of dietary cadmium exposure on reproduction of saltwater cladoceran Moina monogolica Daday: Implications in water quality criteria. Environ. Toxicol. Chem., 29, 365-372 (2010).

Watanabe, T., T. Arakaw, C. Kitajima and S. Fujita: Nutritional evaluation of proteins of living feeds used in seed production of fish. Bull. Jpn. Soc. Fish., 44, 985-988 (1978).

Watanabe, T., C. Kitajima and S. Fujita: Nutritional values of live organisms used in Japan for mass propagation of fish: A Review. Aquaculture, 34, 115-143 (1983).

Watanable, T.: Importance of docosahexaenoic acid in marine larval fish. J. World Aquacult. Soc., 24, 152-161 (1993).

Wilson, R.P.: Handbook of Nutrient Requirements of Finfish (1991): CRC Press (2017)

Zorina-Sakharova, K., A.V. Liashenko and I. Marchenko: Effects of salinity on the zooplankton communities in the Fore-Delta of Kyliya Branch of the Danube River. Acta Zool. Bulg., 2014, 129-133 (2014). 